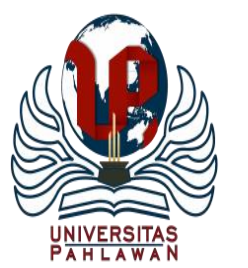

Edukatif : Jurnal Ilmu Pendidikan Volume 3 Nomor 1 Tahun 2021 Halm 14 - 19 EDUKATIF: JURNAL ILMU PENDIDIKAN

Research \& Learning in Education

https://edukatif.org/index.php/edukatif/index

\title{
Analisis Bahasa Ditinjau dari Karakteristik, Isu Belajar dan Teori Bahasa
}

\author{
Yessa Maulida $^{1}$, Neviyarni ${ }^{2}$ \\ Universitas Negeri Padang, Indonesia ${ }^{1,2}$ \\ E-mail : yessamaulida1993@ gmail.com ${ }^{1}$ neviyarni.suhaili911@ @mail.com ${ }^{2}$
}

\begin{abstract}
Abstrak
Artikel ini membahas tentang bahasa dilihat dari karakteristik, isu dan teori belajar bahasa. Bahasa adalah kapasitas khusus yang ada pada manusia untuk memproleh dan menggunakan sistem komunikasi yang kompleks, dan sebuah bahasa adalah contoh spesifik dari sistem tersebut. Isu dalam bahasa antara lain perkembangan bahasa, bahasa dan proses berfikir, bahasa dan binatang, perbedaan budaya di dalam bahasa dan hubungan antara otak dengan bahasa. Kemudian dua teori pendekatan pembelajaran bahasa yaitu conditioning approach dalam pembelajaran bahasa memiliki asumsi dasar bahwa bahasa dipelajari sesuai dengan prinsip pengkondisian, dan pendekatan psikolinguistik.
\end{abstract}

Kata kunci: bahasa, karakteristik, isu, teori

\begin{abstract}
This article discusses language in terms of children, issues and theories of language learning. Language is the special capacity that exists in humans to obtain and use complex communication systems, and a language is a specific example of such a system. Issues in language include language development, language and thought processes, language and animals, cultural differences in language and the relationship between the brain and language. Then the two theories of language learning approaches, namely the conditioning approach in language learning, have a basic assumption that language is studied in accordance with the principles of conditioning and a psycholinguistic approach.
\end{abstract}

Keywords : language, characteristics, issues, theory

Copyright (c) 2021 Yessa Maulida, Neviyarni

$\triangle$ Corresponding author

Email : yessamaulida1993@gmail.com

DOI: https://doi.org/10.31004/edukatif.v3i1.186

ISSN 2656-8063 (Media Cetak)

ISSN 2656-8071 (Media Online) 


\section{PENDAHULUAN}

Manusia tidak dapat terlepas dari bahasa. Bahasa menjadi penguhubung satu individu dengan individu lain dalam berkomunikasi (Kismadewi, 2013). Salah satu pembeda yang paling penting antara manusia dengan makhluk lain adalah kemampuan berbahasa. Walaupun beberapa penelitian mencoba membuktikan perilaku berbahasa binatang seperti chimpanzee, namun perilaku tersebut baru sampai pada tingkat penggunaan bahasa yang sangat sederhana. Bahasa sangat berkaitan dengan proses berfikir (thingking) dan pemecahan masalah (Wikipedia, n.d.). Psikologist Swiss, Jean Piage menganalogi bahasa dari proses berfikir seperti matematika dalam ilmu fisika (Ellis, 1978).

Proses berfikir yang menampilkan kegiatan manusia yang kompleks merupakan aktifitas mental yang dihasilkan dari kemampuan manusia untuk memanipulasi simbol dan konsep yang menggunakannya dengan cara yang berbeda untuk memecahkan masalah. Berfikir sebenarnya mengacu pada kegiatan dan peristiwa terselubung yang tidak teramati langsung oleh manusia, sementara menulis dan berbicara merupakan perilaku bahasa yang terbuka dan teramati langsung. Lebih jauh dari itu proses berfikir mempunyai rentangan dari kegiatan dan peristiwa yang relative sederhana sampai ke aktivitas yang sangat kompleks. Ringkasnya bahasa, proses berfikir dan pemecahan masalah merupakan kegiatan yang sangat erat kaitanya (Ellis, 1978) (Thomas, Linda, 1999)menjelaskan bahwa bahasa sebagai alat yang dipakai untuk membentuk pikiran dan perasaan serta keinginan dan perbuata. Bahasa sebagai alat komunikasi memiliki peranan yang sangat penting dalam kehidupan individu maupun kelompok (Hamdun, n.d.). Bahasa juga merupakan hasil aktivitas manusia (Puspita, n.d.).

Pembelajaran bahasa merupakan aspek penting dalam kehidupan manusia sebagai pencapaian fitrah. Walaupun menurut teori manusia dapat berbahasa hanya dengan melihat bagaimana orang berkomunikasi namun tentunya pengajaran bahasa yang baik perlu diberikan kepada anak. Dengan perkembangan zaman yang begitu pesat sehingga mengubah budaya masyarakat dalam bertutur kata tentunya juga akan berpengaruh pada pembelajaran bahasa anak baik itu pengaruh positif maupun negative (Ellis, 1978).

\section{METODE PENELITIAN}

Artikel ini membahas tentang karakteristik bahasa, isu dan teori belajar bahasa , jenis metode penelitian ini adalah analisis kajian pustaka (literatur research) artikel ini akan memaparkan analisis jurnal ilmiah yang relevan dengan pembahasan yang sudah dipilih, adapun tahap- tahap dalam metode penelitian ini adalah (1) memilih artikel, (2) mengumpulkan data awal, (3) tantangan dari topik, (4) mengumpulkan data pendukung, (5) menghasilkan kesimpulan dan rekomendasi online.

\section{HASIL DAN PEMBAHASAN PENELITIAN}

\section{A. Karakteristik Bahasa}

Unit paling dasar dari bahasa adalah fonem (phonemes) yakni bunyi yang dihasilkan oleh alat ucap manusia yang signifikan dalam membentuk makna (Ellis, 1978). Fonem-fonem tersebut bergabung satu sama lain secara sangat sistematik sehingga membentuk kata yang wakili (represent) simbol yang siap digunakan untuk keperluan komunikasi manusia. Namun demikian simbol yang digunakan simbol yang digunakan untuk komunikasi antara manusia tidak selalu dalam bentuk bunyi ujaran manusia. Simbol tersebut bisa juga dalam bentu gerak, seperti gerakan bagian tubuh, bentuk seperti rambu-rambu lalu lintas dan bahkan bunyi selain bunyi ujaran manusia. Semua tersebut mengacu pada suatu makna yang dapat digunakan sebagai alat komunikasi manusia. Setiap bahasa mempunyai fonem yang berbeda yang merupakan sebab mengapa kita sering kali mendapatkan kesulitan mempelajari kata-kata asing. Bahasa 
lain mungkin menggunakan bunyi bahasa yang tidak pernah ada dalam bahasa kita. Kita mungkin membutuhkan perhatian sejenak untuk mendengarkan fonem baru.

Tingkah laku yang sangat jelas yang membedakan antara manusia dengan binatang lainya adalah kemampuannya berbahasa. Walaupun itu dapat dibuktikan dalam situasi hubungan yang terkontrol dimana sedikit sekali binatang bisa berfikir, mempelajari konsep, mengatasi masalah, maka bahasa sering disebutkan sebagai keitimewaan pembedaan manusia (Talib, 2010).

Bahasa sekurang-kurang nya memiliki empat (4) fungsi (Ellis, 1978):

1. Berfungsi instrumen yakni merupakan perilaku verbal yang dapat mengarahkan reward secara langsung.

2. Bahasa berfungsi sebagai stimulus.

3. Bahasa berfungsi sebagai alat untuk berkomunikasi dengan orang lain.

4. Bahasa berfungsi untuk menyampaikan makna.

Seperti yang telah dikatakan bahwa bahasa terbentuk dari bunyi yang disebut dengan Fonem. Fonem dapat pula dibedakan aras beberapa bentuk yang berbeda yaitu nassal atau oral yang berkategori

- explosif dan noneksplosif

- vowels, constans atau diphtongs.

Phonem kemudian bergabung membentuk unit yang lebih tinggi yang disebut dengan Morphems. Morphems adalah unit terkecil dari bahasa yang memiliki makna. Dari sumber lain mendefenisikan morphems sebagai unit terkecil linguistik yang mempunyai makna. Morfem biasanya terdiri dari sekurang-kurangnya gabungan dari beberapa fonem. Kajian tentang bunyi ujar bunyi bahasa sehingga membentuk bahasa disebut dengan phonology, sedangkan kajian tentang morfom disebut morphology. Analisis linguistik yang lebih tinggi dari dua analisis dasar diatas adalah (Sujadi, 2013):

\section{Analisis tingkat kandungan lexical}

Analisis bahasa berkisar sekitar pertanyaan yang digunakan di dalam sebuah bahasa. Kajian ini terbatas pada kata, seperti persamaan kata, lawan kata dan bagaimana menggunakan kata tersebut dalam kalimat.

\section{Tingkat kandungan syntactic}

Arah kajian bahasa adalah susunan atau urutan kata untuk membentuk prase dan kalimat. Aturan yang mengatur elemen-elemen bahasa membentuk frasa dan kalimat disebut dengan grammar (tata bahasa).

\section{Analysis kandungan semantic}

Kajian bahasa berkisar sekitar pertanyaan apa yang ingin dikomunikasikan oleh sebuah wacana atau bahasa dan apa makna dari sebuah kalimat. Dengan kata lain kajian semantic berfokus pada makna bahasa. Untuk memahami bahasa pada orang dewasa, kita perlu mempelajari struktur kalimat ke dalam bentuk frasa (phrases), yakni pengelompokan kata-kata. Struktur kalimat berdasarkan kelompok kata disebut Phrase Sturcture. Kalimat pada dasarnya terdiri dari dua prase dasar yaitu (Sunarto \& Hartono, 2006):

\section{a. frase benda (noun phrase)}

- determinant

- noun 


\section{b. frase kerja (verb phrase)}

- kata kerja

- noun phrase: determiner dan kata bernda

Ahli bahasa membedakan antara struktur dalam Deep Structure dan surface structure. Deep strucuture mengacu pada makna dari kalimat yakni hubungan antara kata di dalam kalimat sedangkan surface structure adalah kalimat tersebut sebagaimana ia diucapkan yang hanya mencerminkan kaitan antara bagianbagian kalimat tersebut.

Bahasa sebagai alat bantu penyampaian pesan memiliki cirri-ciri (Wicaksono, 2016) :

1. Bahasa bersifat simbolik

2. Makna ada pada orang, tidak pada kata-kata

3. Bahasa membentuk persepsi individu

4. Bahasa mencerminkan sikap individu

\section{B. Isu - Isu dalam Bahasa}

Dalam kajian tentang bahasa banyak hal yang bisa dijadikan pokok bahasan. Namun dalam bagian ini akan dibicarakan beberapa saja, antara lain perkembangan bahasa, bahasa dan proses berfikir, bahasa dan binatang, perbedaan budaya di dalam bahasa dan hubungan antara otak dengan bahasa (Ellis, 1978). Permulaan dari Perkembangan bahasa manusia adalah Babbling, yang merupakan tipe dasar dari vokalisasi. Anak-anak menghasilkan bunyi sebelum berusia enam bulan ,tetapi belum berbentuk bunyi bahasa, ia hanya meniru bunyi bahasa. Perkembangan struktur bahasa sangat kompleks dan memerlukan penerapan prinsip dibalik pembentukan stimulus-respon.

Walaupun bahasa dan proses berfikir merupakan peristiwa yang sangat erat kaitannya, bahasa kelihatannya tidak merupakan hal esensial bagi proses mental yang kompleks, walaupun bahasa itu sendiri membantu pemecahan masalah. Bahasa tidak merupakan faktor yang penting di dalam perkembangan kapasitas kognitif manusia (Fahrurozi, 2014). Salah satu kajian yang berupaya menghubungkan bahasa dengan proses berfikir adalah hipotesis relatif bahasa ( linguistik relativity hypotesis) yang dikembangkan oleh Benjamin Worth. Ia berhipotesis bahwa struktur bahasa seseorang mengarahkan seseorang untuk memahami dunia dengan cara tertentu, yakni dengan cara yang berbeda dari yang digunakan seseorang di dalam bahasa yang berbeda. Ada dua versi hipotesis yang dikembangkan nya yaitu (Atkinson, 2008):

a. Strong version, Yang menekankan bahwa bahasa secara konstan mempengaruhi proses berfikir.

b. Wean version Yang menekankan bahwa bahasa mempengaruhi proses berfikir, bila suatu tugas secara langsung tergantung pada proses sistem bahasa.

Sebuah penelitian yang menggunakan binatang chimpanzee dilakukan oleh ahli psikologi untuk melihat apakah binatang mempunyai bahasa. Dari kesimpulan yang didapat yaitu chimpanzhee mempunyai kekurangan sistem alat ucap untuk bisa berbicara seperti manusia. Ternyata chimpanzee mampu memahami labih dari satu simbol dengan baik. Kesimpulannya adalah bahwa binatang memiliki bahasa, karena binatang tidak mampu memproduksi kalimat. Salah satu jawaban yang mungkin bisa dijadikan patokan adalah bahwa binatang tidak memiliki aspek bahasa yang unik pada manusia yakni self-reflexive quality yaitu kualitas perujukan sesuatu pada dirinya sendiri.

Pertanyaan lain yang menarik untuk dibahas dalam isu bahasa adalah bagaimana perbedaan individu di dalam bahasa dapat dijelaskan, khususnya bagaimana perkembangan budaya, wilayah, dan perbedaan etnik di 
dalam bahasa. banyak ahli sosiolinguistik menyatakan bahwa budaya dan aspek sosial lainnya mempunyai pengaruh yang besar dalam keragaman bahasa (Yunisari, 2014).

Isu terakhir dalam hal bahasa adalah bagaimana hubungan bahasa dengan otak. Otak manusia terbagi atas dua hemispheres, yang tidak berfungsi sama. Masing-masing dari hemispheres tersebut menerima informasi dari indera, tetapi keduanya menerima informasi yang terpisah. Informasi yang lingkungan visual biasanya dibagi, informasi dari lingkungan visual kiri diproyeksikan ke hemisphere bagian kanan dan informasi dari lingkungan visual kiri diproyeksikan ke hemisphere bagian kanan begitu juga sebaliknya (Desmita, 2008).

\section{Teori Belajar Bahasa}

Secara umum ada dua pendekatan pembelajaran bahasa (Saepudin, 2018) yaitu :

1. Pendekatan Pengkondisian (conditioning approach)

Pendekatan pembiasaan dalam mempelajari bahasa didasari atas prinsip dasar pembiasaan. Menurut pandangan B.F Skinner anak-anak belajar bahasa sama caranya dengan mereka mempelajari semua tingkah laku. Gagasan dasarnya adalah bahwa perilaku lisan/verbal seperti perilaku diperoleh melalui penguatan dari respon verbal yang tepayt. Dalam pembelajaran bahasa memiliki asumsi dasar bahwa bahasa dipelajari sesuai dengan prinsip pengkondisian yang memiliki gagasan dasar bahwa perilaku verbal (verbal bihavior) sama seperti perilaku lainnya, didapatkan melalui penguatan respon yang benar. Prinsip penjenarilasian dan pendiskriminasian berperan di dalam teori belajar bahasa dengan pendekatan pengkondisian. Contoh : seorang anak akan diberi hadiah oleh orang tuanya jika ia mengucapkan kata "anjing". Setelah anak mengucapkan apa yang diajarkan oleh orang tuanya maka ia diberi hadiah seperti kue, dsb.

\section{Pendekatan Psikolinguistik}

Noam Chomsky sangat mengkritik sangat mengkritik teori pembiasaan bahasa yang dikemukakan oleh Skinner. Menurutnya anak belajar suatu perangkat aturan yang kompleks dalam pembelajaran bahasa, walaupun mereka tidak bisa menjelaskan aturan tersebut. terlebih lagu, anak belajar aturan ini tanpa perlu memiliki seseorang untuk mengajari mereka dalam formal sense, dan mereka belajar aturan ini diusia yang sangat muda. Menurut psikonguistik kemampuan untuk mengembangkan sebuah aturan abstrak untuk menghasilkan bahasa adalah unik untuk manusia Beranggapan bahwa anak mempelajari aturan-aturan bahasa yang kompleks pada saat ia belajar sebuah bahasa, walaupun mereka tidak mampu memverbalisasikan atau menjelaskan aturan-aturan tersebut. Anak-anak mendapatkan aturan tersebut tanpa harus diajarkan oleh orang lain dalam bentuk yang formal dan mereka mendaptkan hukum-hukum bahasa ini pada usia yang sangat dini.

\section{KESIMPULAN}

Bahasa memainkan peranan yang penting dalam pembelajaran. Unit dasar dari bahasa adalah phonemes dan morphenes. Kalimat dipengaruhi oleh dua hal yakni struktur permukaan dan struktur dalam. Selanjutnya tentang isu-isu dalam bahasa diantaranta dibicarakan tentang perkembangan bahasa, bahasa dan pikiran, bahasa hewan, perbedaan budaya pada bahasa, dan bahasa dan otak. Kesemuanya itu tentuntunya harus dipahami oleh setiap manusia terutama pendidik dalam mengajarkan bahasa. Mempelajari bahasa tentunya tidak terlepas dari teori-teori pembelajaran bahasa yakni teori pengkondisian dan teori psikolinguistik. Menurut teori pembiasaan anak mempelajari bahasa dari orang-orang yang ada disekitarnya, teori ini juga berbicara tentang pemberian hadiah jika anak mampu mengucapkan sebuah kalimat. Teori psikolinguistik berpendapat bahwa anak belajar suatu perangkat aturan yang kompleks dalam pembalajarn bahasa. 


\section{DAFTAR PUSTAKA}

Atkinson, R. (2008). Pengantar Psikologi. Erlangga.

Desmita. (2008). Psikologi Perkembangan. PT Remaja Rosdakarya.

Ellis, H. (1978). Fundamental of Human Learning, Memory and Cognition.

Fahrurozi. (2014). Perkembangan Bahasa pada Anak. Http://Fahrurozel.Blogspot.Com/2013/12/MakalahPsikologi-Tentang-Bahasa.Html.

Hamdun, D. (n.d.). Psikologi Belajar Bahasa. Jurnal Pendidikan Bahasa Arab UIN SUSKA Riau Al'Arabiyah, 2.

Kismadewi, K. (2013). Psikologi Perkembangan Bahasa. Http://Kkisma.Blogspot.Com/2013/12/PsikologiPerkembangan-Bahasa.Html.

Puspita, Y. (n.d.). Pendekatan Psikologis dalam Penguasaan Bahasa.

Saepudin, S. (2018). Teori Linguistik dan Psikologi dalam Pembelajaran Bahasa. Al-Islah Jurnal Pendidikan Islam, $16(1), 100-118$.

Sujadi, E. (2013). Bahasa: Psikologi Belajar. Http://Ekosujadi-Bintan.Blogspot.Com/2013/02/BahasaPsikologi-Belajar.Html.

Sunarto \& Hartono, N. B. . (2006). Perkembangan Peserta Didik. Rineka Cipta.

Talib, R. (2010). Psikologi dan Metode Pembelajaran Bahasa. Jurnal Inovasi, 7 (04).

Thomas, Linda, dkk. (1999). Bahasa, Masyarakat dan Kekuasaan (Alih Bahasa Sunoto,dkk). Pustaka Belajar.

Wicaksono, L. (2016). Bahasa dalam Komunikasi Pembelajaran. Jurnal Pembelajaran Prospektif, 1 (2).

Wikipedia. (n.d.). Bahasa. Https://Id.Wikipedia.Org/Wiki/Bahasa.

Yunisari, P. (2014). Psikologi Belajar Bahasa. Http://Sinebriller.Blogspot.Com/2014/11/PerkembanganBahasa-Makalah-Psikologi.Html. 